\title{
The relationship between the insertion/deletion gene polymorphism of ACE and atrial fibrillation in Chinese population: a meta-analysis
}

\author{
Yu-xiang $\mathrm{ZHU}^{1}$, Gang LIU ${ }^{1 *}$ (iD
}

\begin{abstract}
Introduction: In this study, we aimed to explore the relationship between the I/D gene polymorphism of ACE and the risk of AF in Chinese population. Materials and methods: Studies searched in several databases from beginning to July 2019 were included in our study. After screening by evaluation, thirteen articles were selected. Results: Our results showed that I/D gene polymorphism of ACE increased the risk of AF. The stratified analyses by case types and control sources suggested a markedly increased association in lone $\mathrm{AF}$, hypertensive patients with $\mathrm{AF}$, and un-typed $\mathrm{AF}$, as well as in studies with hospital person and healthy person. The stratified geographical analysis indicated the risk of AF increased significantly in North China. Conclusions: All in all, our results indicated the marked relationship between I/D gene polymorphism of ACE and the increased risk of AF in Chinese population.
\end{abstract}

Keywords: atrial fibrillation; insertion/deletion; gene polymorphism; angiotensin-converting enzyme.

Practical Application: Explore the relationship between the gene polymorphism of ACE and the risk of AF in Chinese population.

\section{Introduction}

Atrial fibrillation $(\mathrm{AF})$ is the most common persistent arrhythmia with highest incidence among all the atrial arrhythmias. With the increase of age, the incidence of AF is increasing, and it can reach $10 \%$ in people over 75 years old (Hart \& Halperin, 2001). The mortality in patients with AF is much higher than that in patients without AF (Benjamin EJ et al., 1998) There are many causes of atrial fibrillation, mainly diseases of the heart itself. Common factors include genetic factors, hypertension and heart disease, such as coronary heart disease (Fatkin et al., 2007). To date, several candidate genes, such as angiotensin-converting enzyme (ACE), have been implicated in cardiovascular disease, such as essential hypertension, myocardial infarction, and so on(Sayed-Tabatabaei et al., 2006; Zintzaras et al., 2008; Rudnicki \& Mayer, 2009).Among these candidate gene polymorphisms, the insertion (I) or deletion (D) of $287 \mathrm{bp}$ Alu repeat sequence is a hotspot of AF gene variants. It has been reported that the polymorphism includes homozygous D/D, I/I and heterozygous I/D. Yamashita et al. was the first one to investigate the relationship between gene polymorphism of I/D in ACE and AF in Japanese in 1997 (Yamashita et al., 1997). In addition, many epidemiological studies which have been performed to explore the relationship between polymorphism of ACE-I/D and individual susceptibility to $\mathrm{AF}$ were inconsistent. The reason may be due to the ethnic and regional differences of the subjects and the limit of the number of subjects per time. To decrease the interfere factors of genetic differences, we conducted a meta-analysis to explore the relationship between the polymorphism of ACE-I/D and the risk of $\mathrm{AF}$ in Chinese.

\section{Subjects and methods}

\subsection{Identification of eligible studies}

Articles published in PubMed, Embase, Web of Science, the Cochrane Library, the Chinese Biomedical Database, and CNKI databases from beginning to July 2019 were searched. The following terms were used: angiotensin converting enzyme AND atrial fibrillation AND polymorphism. Literature search is not limited to language. Moreover, the reference lists of identified studies were manually checked to include other potentially eligible articles. We would select papers when they satisfied those criteria: (1) studies with case-control or cohort; (2) the studies which were to explore the relationship between gene polymorphism of I/D in ACE and the risk of AF; (3) studies with genotype or allele frequencies in patients and control person; (4) studies reported in Chinese population; (5) studies with complete data. However, if studies were review, letter, case report, and editorial article, then they were excluded.

\subsection{Data extraction}

Data were extracted from eligible articles by 2 researchers, respectively. They firstly screened the titles and abstracts of all eligible literatures. If the title and abstract were inconclusive, the full text was reviewed. If the two researchers had different suggestion, it was up to them to discuss. Each study was collected available genotype data for the following characteristics: name of first author, case type, publication year, source of controls, geographic area, sample size, and gene polymorphism of ACE-I/D. 


\subsection{Statistical analysis}

The pooled OR and 95\% CIs were used to evaluate the relationship between gene polymorphism and AF. This study detected the relevance between $\mathrm{D}$ allele and $\mathrm{AF}$ risk which was relative to the I allele, and the comparison between homozygote DD and II, DD and (II+ID), and (DD+ID) and II. Chi-square based Q-test was carried out to evaluate the heterogeneity. If two studies had no significant heterogeneity, OR was pooled using the fixed-effects model. If not, the random-effects model was used. The consistency between the two models was compared to explore sensitivity. The potential publication bias was assessed through funnel plot. Statistical analysis was performed with Stata12.0. It was considered to be statistically different when $P<0.05$.

\section{Results}

\subsection{The included studies}

After searching the articles from these databases, 18 relevant articles were preliminarily included. Finally, there were 13 studies(Wang et al., 2003; Tsai et al., 2004; Chen et al., 2007; Chang et al., 2007; Tsai et al., 2008; Wei et al., 2008; Huang et al., 2009; Yang et al., 2009; Wang et al., 2011;
Zhang et al., 2011; Zhang et al., 2012; Nan et al., 2012; Jin et al., 2013) in this study. In addition, a total of 2029 patients with AF and 3371 control person were included. They were used to evaluate the relationship between gene polymorphism of ACE-I/D and AF risk in Chinese. According to case types of included studies, 686 non-familial structural AF cases, 534 hypertensive patients with AF and 246 lone AF cases were identified. The controls were selected from hospitalized patients. The basic information of each individual article were shown in Table 1.

\subsection{The relationship between gene polymorphism of ACE-I/D and $A F$}

The relationship between gene polymorphism of ACE-I/D and AF was illustrated in Table 2. In the overall population, the pooled results showed an increased AF risk with the polymorphism (Table 2, Figure 1). The stratified analysis by case type indicated a significant increased association for lone AF, hypertensive patients with AF, and un-typed AF (Table 2). The stratified analysis by controls also showed a notably increased correlation both in studies with hospital-based controls and in studies with healthy controls (Table 2). The stratified geographic analysis suggested a markedly increased risk of AF in North

Table 1. Characteristics of the studies that were included in the meta-analysis.

\begin{tabular}{|c|c|c|c|c|c|c|c|c|c|c|c|c|}
\hline \multirow[b]{2}{*}{ References } & \multirow[b]{2}{*}{ Case type } & \multirow{2}{*}{$\begin{array}{l}\text { Source of } \\
\text { controls }\end{array}$} & \multirow{2}{*}{$\begin{array}{l}\text { Geographic } \\
\text { location }\end{array}$} & \multirow{2}{*}{$\begin{array}{c}\text { Case } \\
\text { number }\end{array}$} & \multirow{2}{*}{$\begin{array}{l}\text { Control } \\
\text { number }\end{array}$} & \multicolumn{3}{|c|}{ Cases } & \multicolumn{3}{|c|}{ Controls } & \multirow{2}{*}{$\begin{array}{l}\text { HWE in } \\
\text { control, } \\
\text { P-value }\end{array}$} \\
\hline & & & & & & II & ID & DD & II & ID & $\mathrm{DD}$ & \\
\hline Wang et al. (2003) & Lone AF & $\begin{array}{l}\text { Healthy } \\
\text { subjects }\end{array}$ & Beijing & 53 & 50 & 16 & 26 & 11 & 18 & 24 & 8 & 1.000 \\
\hline Wang et al. (2003) & $\begin{array}{c}\text { Hypertensive } \\
\text { patients with AF }\end{array}$ & $\begin{array}{l}\text { Hospitalized } \\
\text { patients }\end{array}$ & Beijing & 32 & 38 & 11 & 16 & 5 & 13 & 18 & 7 & 0.861 \\
\hline Tsai et al. (2004) & $\begin{array}{l}\text { Non-familial } \\
\text { structural AF }\end{array}$ & $\begin{array}{l}\text { Hospitalized } \\
\text { patients }\end{array}$ & Taiwan & 250 & 250 & 98 & 98 & 54 & 84 & 105 & 61 & 0.016 \\
\hline Chen et al. (2007) & Persistent AF & $\begin{array}{l}\text { Hospitalized } \\
\text { patients }\end{array}$ & Zhejiang & 40 & 36 & 13 & 20 & 7 & 13 & 17 & 6 & 0.912 \\
\hline Chang et al. (2007) & $\begin{array}{l}\text { Non-familial } \\
\text { structural AF }\end{array}$ & $\begin{array}{l}\text { Hospitalized } \\
\text { patients }\end{array}$ & Heilongjiang & 189 & 194 & 87 & 52 & 50 & 120 & 44 & 30 & $<0.001$ \\
\hline Tsai et al. (2008) & $\begin{array}{l}\text { Non-familial } \\
\text { structural AF }\end{array}$ & $\begin{array}{l}\text { Hospitalized } \\
\text { patients }\end{array}$ & Taiwan & 227 & 1009 & 89 & 88 & 50 & 297 & 496 & 216 & 0.739 \\
\hline Wei et al. (2008) & $\begin{array}{l}\text { Documented } \\
\text { structural AF }\end{array}$ & $\begin{array}{c}\text { Patients/ } \\
\text { healthy subjects }\end{array}$ & Yunnan & 55 & 63 & 14 & 23 & 18 & 23 & 28 & 12 & 0.509 \\
\hline Huang et al. (2009) & $\begin{array}{c}\text { Hypertensive } \\
\text { patients with AF }\end{array}$ & $\begin{array}{l}\text { Hospitalized } \\
\text { patients }\end{array}$ & Fujian & 97 & 529 & 37 & 40 & 20 & 264 & 222 & 43 & 0.700 \\
\hline Yang et al. (2009) & $\begin{array}{l}\text { Non-familial } \\
\text { structural AF }\end{array}$ & $\begin{array}{l}\text { Hospitalized } \\
\text { patients }\end{array}$ & Guangdong & 20 & 30 & 7 & 6 & 7 & 8 & 8 & 14 & 0.015 \\
\hline Wang et al. (2011) & $\mathrm{AF}$ & $\begin{array}{l}\text { Hospitalized } \\
\text { patients }\end{array}$ & Chongqing & 148 & 157 & 60 & 70 & 18 & 68 & 69 & 20 & 0.703 \\
\hline Zhang et al. (2011) & $\mathrm{AF}$ & $\begin{array}{l}\text { Hospitalized } \\
\text { patients }\end{array}$ & Hubei & 120 & 120 & 32 & 49 & 39 & 52 & 46 & 22 & 0.046 \\
\hline Zhang et al. (2012) & Lone AF & $\begin{array}{l}\text { Healthy } \\
\text { subjects }\end{array}$ & Shanghai & 193 & 297 & 68 & 87 & 38 & 129 & 139 & 29 & 0.337 \\
\hline Nan et al. (2012) & $\mathrm{AF}$ & $\begin{array}{l}\text { Hospitalized } \\
\text { patients }\end{array}$ & Xinjiang & 200 & 200 & 32 & 90 & 78 & 68 & 80 & 52 & 0.006 \\
\hline Jin et al. (2013) & $\begin{array}{c}\text { Hypertensive } \\
\text { patients with AF }\end{array}$ & $\begin{array}{l}\text { Hospitalized } \\
\text { patients }\end{array}$ & Henan & 405 & 398 & 143 & 157 & 105 & 146 & 200 & 52 & 0.199 \\
\hline
\end{tabular}


Original Article

Zhu; Liu

Table 2. Association of the ACE I/D gene polymorphism and AF in Chinese population.

\begin{tabular}{|c|c|c|c|c|c|}
\hline \multicolumn{2}{|c|}{ Analysis model } & $\begin{array}{c}\mathrm{n} \\
14\end{array}$ & $\frac{\mathrm{ORr}(95 \% \mathrm{CI})}{1.29(1.07-1.55)}$ & $\frac{\text { ORf }(95 \% \mathrm{CI})}{1.26(1.16-1.37)}$ & $\frac{P_{h}}{0.000}$ \\
\hline & Lone AF & 2 & $1.43(1.12-1.81)$ & $1.43(1.12-1.81)$ & 0.585 \\
\hline & Hypertensive patiens with AF & 3 & $1.40(1.11-1.77)$ & $140(1.19-1.65)$ & 0.218 \\
\hline & Non-familial structural AF & 4 & $1.00(0.66-1.52)$ & $0.98(0.85-1.12)$ & 0.000 \\
\hline & $\mathrm{AF}$ & 3 & $1.55(1.06-2.26)$ & $1.57(1.30-1.88)$ & 0.018 \\
\hline & Hospitalized patients as controls & 11 & $1.25(1.00-1.56)$ & $1.23(1.12-1.34)$ & 0.000 \\
\hline & North China & 5 & $1.51(1.23-1.87)$ & $1.51(1.32-1.73)$ & 0.107 \\
\hline & South China & 9 & $1.19(0.94-1.52)$ & $1.12(1.01-1.25)$ & 0.000 \\
\hline \multirow[t]{7}{*}{ DD vs. II } & Total analysis & 14 & $1.65(1.17-2.32)$ & $0.99(0.82-1.19)$ & 0.000 \\
\hline & Non-familial structural AF & 4 & $1.00(0.55-1.81)$ & $0.99(0.77-1.27)$ & 0.004 \\
\hline & $\mathrm{AF}$ & 3 & $2.17(1.10-4.28)$ & $2.30(1.60-3.30)$ & 0.037 \\
\hline & Healthy subjects as cotrols & 2 & $2.26(1.36-3.75)$ & $2.26(1.36-3.74)$ & 0.463 \\
\hline & Hospitalized patients as controls & 11 & $1.53(1.02-2.29)$ & $1.49(1.26-1.77)$ & 0.000 \\
\hline & North China & 5 & $2.24(1.71-2.92)$ & $2.23(1.72-2.91)$ & 0.400 \\
\hline & South China & 9 & $1.46(0.91-2.33)$ & $1.27(1.03-1.56)$ & 0.000 \\
\hline \multirow[t]{4}{*}{ DD vs. II+ID } & Total analysis & 14 & $1.54(1.20-1.99)$ & $1.55(1.34-1.78)$ & 0.002 \\
\hline & Lone AF & 2 & $2.04(1.28-3.24)$ & $2.03(1.28-3.23)$ & 0.388 \\
\hline & Hypertensive patiens with $\mathrm{AF}$ & 3 & $2.25(1.43-3.53)$ & $2.30(1.70-3.11)$ & 0.196 \\
\hline & South China & 9 & $1.42(1.00-2.01)$ & $1.32(1.10-1.59)$ & 0.003 \\
\hline \multirow[t]{9}{*}{ DD+ID vs. II } & Total analysis & 14 & $1.28(1.00-1.65)$ & $1.19(1.06-1.35)$ & 0.000 \\
\hline & Lone AF & 2 & $1.39(0.99-1.96)$ & $1.39(0.99-1.96)$ & 0.859 \\
\hline & Hypertensive patiens with AF & 3 & $1.21(0.90-1.63)$ & $1.19(0.94-1.51)$ & 0.279 \\
\hline & Non-familial structural AF & 4 & $0.93(0.54-1.62)$ & $0.89(0.73-1.09)$ & 0.000 \\
\hline & $\mathrm{AF}$ & 3 & $1.84(1.07-3.16)$ & $1.81(1.37-2.39)$ & 0.026 \\
\hline & Healthy subjects as cotrols & 2 & $1.39(0.99-1.96)$ & $1.39(0.99-1.96)$ & 0.859 \\
\hline & Hospitalized patients as controls & 11 & $1.24(0.92-1.69)$ & $1.15(1.01-1.32)$ & 0.000 \\
\hline & North China & 5 & $1.54(1.01-2.35)$ & $1.46(1.20-1.78)$ & 0.010 \\
\hline & South China & 9 & $1.16(0.85-1.57)$ & $1.06(0.91-1.23)$ & 0.001 \\
\hline
\end{tabular}

China via the four model, while there was no significant risk in South China (Table 2).

\subsection{Sensitive analysis and publication bias diagnosis}

The sensitivity of this meta-analysis was assessed by comparing the pooled results between the two models. The ORs of marked combinations did not change. Furthermore, the sensitivity analysis showed that the data were metastable (Table 2). The publication bias was evaluated by Begg's funnel plot (Figure 2), in which the shape did not show remarkable asymmetry. Moreover, the results of Egger's test suggested that there was no noteworthy publication bias in all studied articles (Figure 3). 


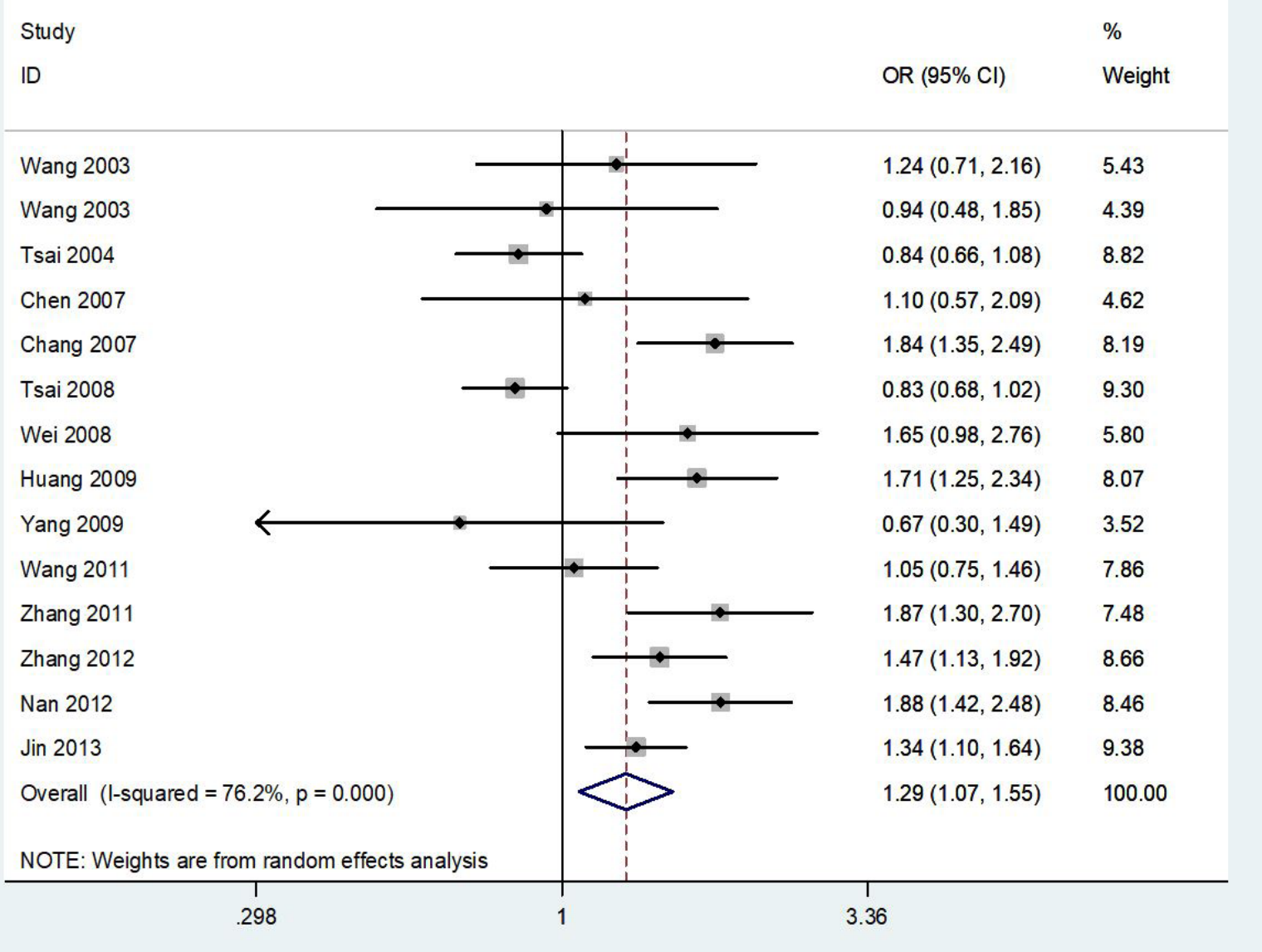

Figure 1. Forest plot for the association between ACE I/D gene polymorphism and AF under the allele random-effect model.

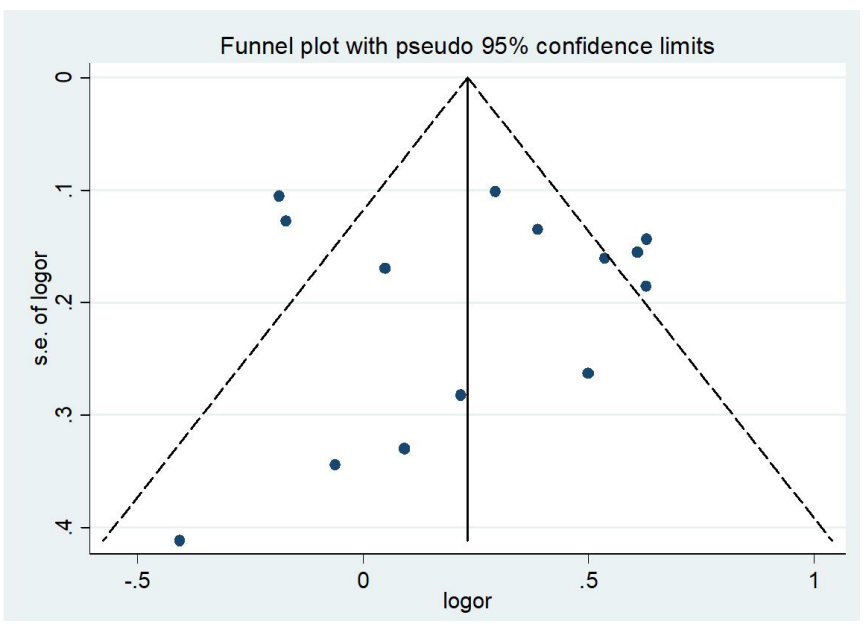

Figure 2. Publication bias assessment of ACE I/D gene polymorphism and AF susceptibility with Begg's funnel plot.

\section{Discussion}

In recent years, more and more studies began to pay attention to the genetic susceptibility of AF. More importantly, some studies have shown that genetic variation of ACE-I/D gene plays an significant role in the occurrence and development of

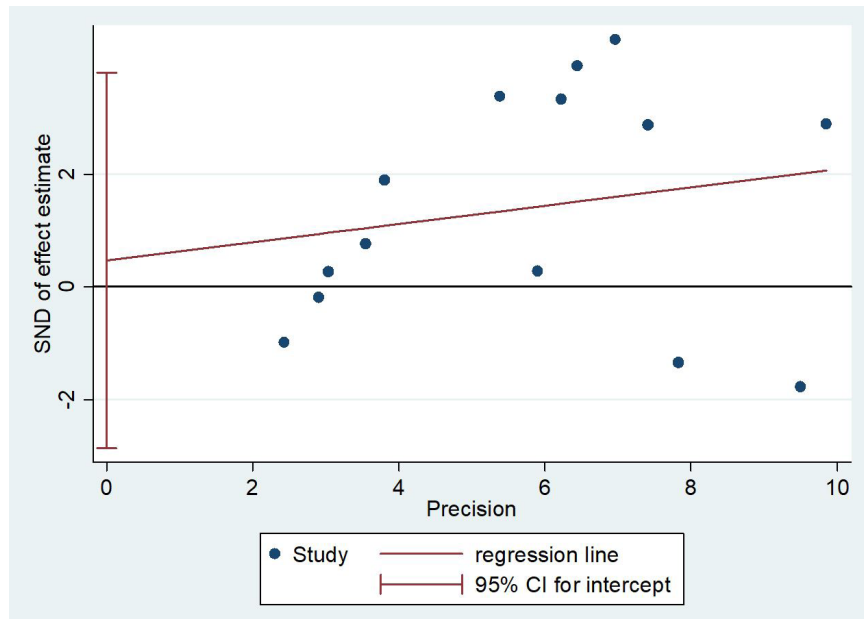

Figure 3. Egger's linear regression for the Begg's funnel plot.

AF (Chang et al., 2007; Huang et al., 2009; Zhang et al., 2011; Zhang et al., 2012; Nan et al., 2012; Jin et al., 2013). ACE is an important component of renin - Angiotension - aldosterone. Some studies have shown that ACE I/D gene is highly expressed in heart tissue. ACE can act on adrenal cortex, promote the 
secretion of aldosterone, and lead to atrial fibrosis and uneven conduction, resulting in the increased substrate of AF. The effect of gene polymorphism of ACE-I/D on the progression of AF has been studied, but the results are not consistent. This may be due to the differences in sample size, cardiovascular disease and race.

Therefore, we conducted this study to estimate the relationship between gene polymorphism of ACE-I/D and AF risk, and the article about Chinese was limited to reduce the effect of racial differences. Our results indicated that gene polymorphism of ACE I/D was markedly associated with AF risk in Chinese. We further performed subgroup analyses to investigate the validity of case type, source of controls and geographical location. Significant association was found about gene polymorphism of ACE-I/D on $\mathrm{AF}$ risk in all the subgroups for lone AF, hypertensive patients with AF, un-typed AF, studies with hospital-based controls, studies with healthy controls and the population from North China, while no association was found in non-familial structural $\mathrm{AF}$ and the population from South China.

Previously, there were two published meta-analyses which had paid attention to gene polymorphism of ACE-I/D and its association with AF risk (Liu et al., 2011; Ma et al., 2015). Liu et al. (2011) conducted a meta-analysis in which there were 18 case-control studies with 7577 patients and there were no marked associations between the gene polymorphism of ACE-I/D and AF risk in genetic additive model and dominant model, but there was a marked relevance in the recessive model. However, the authors suggested that their results cannot show an association between gene polymorphism of ACE-I/D and AF risk. In 2015, Ma et al (Ma et al., 2015) performed an evaluation of the relevance in 23 case-control studies. Their results indicated that gene polymorphisms of ACE I/D were notably associated to ethnicity, as well as AF. To some extent, those results indicated that gene polymorphism of ACE-I/D might be related to AF risk in Chinese.

There were some advantages in our study. We strictly implemented the inclusion and exclusion criteria to decrease selection deviation in highest measure. In addition, the inclusion of non-English articles will also minimize bias. Furthermore, we explored the effect of the geographic area and case type with regard to the risk of AF with relevance to polymorphism of ACE-I/D. However, there were also some limitations. There were only data from a single ethnic group in this conducted (ethnic-specific) meta-analysis. Besides, we had not study other factors involved in AF, including age, smoking, etc. It could cause potential bias. Furthermore, the etiology of osteoporosis is very complex, which is regulated by activities of gene-gene and gene-environment interactions. Due to the lack of relevant data, we did not consider the interaction of these factors.

In conclusion, we provided strong evidence to indicate that gene polymorphisms of ACE-I/D were related to AF risk in Chinese. In addition, subgroup analysis revealed a marked correlation in various $\mathrm{AF}$ case types and geographic areas. However, the gene polymorphisms of ACE-I/D is not the only factor related to AF risk, and further studies are necessary to explore the potential relevance with gene-gene and gene-environment interactions.

\section{References}

Benjamin, E. J., Wolf, P. A., D’Agostino, R. B., Silbershatz, H., Kannel, W. B., \& Levy, D. (1998). Impact of atrial fibrillation on the risk of death: The Framingham Heart Study. Circulation, 98(10), 946-952. http://dx.doi.org/10.1161/01.CIR.98.10.946. PMid:9737513.

Chang, H., Yang, S. \& Han, W. (2007). Associations of the polymorphisms in renin-angiotensin system with nonfamilial structural atrial fibrillation. Heilongjiang Medical Journal, 31, 731-33.

Chen, X., Ling, F. \& Shen, F. (2007). The study of the association between the insertion/deletion (I/D) polymorphism of angiotensinconverting enzyme (ACE) gene and atrial fibrillation. Zhejiang Medical Journal, 29, 908-910.

Fatkin, D., Otway, R., \& Vandenberg, J. I. (2007). Genes and atrial fibrillation: A new look at an old problem. Circulation, 116(7), 782792. http://dx.doi.org/10.1161/CIRCULATIONAHA.106.688889. PMid:17698744.

Hart, R. G., \& Halperin, J. L. (2001). Atrial fibrillation and stroke: Concepts and controversies. Stroke, 32(3), 803-808. http://dx.doi. org/10.1161/01.STR.32.3.803. PMid:11239205.

Huang, M., Gai, X., Yang, X., Hou, J., Lan, X., Zheng, W., Chen, F., \& He, J. (2009). Functional polymorphisms in ACE and CYP11b2 genes and atrial fibrillation in patients with hypertensive heart disease. Clinical Chemistry and Laboratory Medicine, 47(1), 32-37. http:// dx.doi.org/10.1515/CCLM.2009.023. PMid:19117407.

Jin, Y., Qiu, C. G., Hou, Y. T., Wang, Z. F., \& Liu, Z. Q. (2013). Correlation between angiotensin converting enzyme gene insertion deletion polymorphism and AF in patients with primary hypertension. Chinese Journal of Cerebral Vascular Disease Heart, 15, 906-908.

Liu, T., Korantzopoulos, P., Xu, G., Shehata, M., Li, D., Wang, X., \& Li, G. (2011). Association between angiotensin-converting enzyme insertion/deletion gene polymorphism and atrial fibrillation: A meta-analysis. Europace, 13(3), 346-354. http://dx.doi.org/10.1093/ europace/euq407. PMid:21076147.

Ma, R., Li, X., Su, G., Hong, Y., Wu, X., Wang, J., Zhao, Z., Song, Y., \& Ma, S. (2015). Angiotensin-converting enzyme insertion/ deletion gene polymorphisms associated with risk of atrial fibrillation: A meta-analysis of 23 case-control studies. Journal of the ReninAngiotensin-Aldosterone System, 16(4), 793-800. http://dx.doi. org/10.1177/1470320315587179. PMid:26041129.

Nan, Y., Mu, H., Lu, W., Liu, Z., He, P., \& Yang, Y. (2012). Polymorphism of ACE gene I/D of atrial fibrillation patients in Xinjiang Kazakh and Han nationality. Journal of Chinese General Practice, 15(14), 1603-1606.

Rudnicki, M., \& Mayer, G. (2009). Significance of genetic polymorphisms of the renin-angiotensin-aldosterone system in cardiovascular and renal disease. Pharmacogenomics, 10(3), 463-476. http://dx.doi. org/10.2217/14622416.10.3.463. PMid:19290794.

Sayed-Tabatabaei, F. A., Oostra, B. A., Isaacs, A., van Duijn, C. M., \& Witteman, J. C. (2006). ACE polymorphisms. Circulation Research, 98(9), 1123-1133. http://dx.doi.org/10.1161/01. RES.0000223145.74217.e7. PMid:16690893.

Tsai, C. T., Hwang, J. J., Chiang, F. T., Wang, Y. C., Tseng, C. D., Tseng, Y. Z., \& Lin, J. L. (2008). Renin-angiotensin system gene polymorphisms and atrial fibrillation: a regression approach for the detection of gene-gene interactions in a large hospitalized population. Cardiology, 111(1), 1-7.

Tsai, C. T., Lai, L. P., Lin, J. L., Chiang, F. T., Hwang, J. J., Ritchie, M. D., Moore, J. H., Hsu, K. L., Tseng, C. D., Liau, C. S. \& Tseng, Y. Z. (2004). Renin-angiotensin system gene polymorphisms and atrial fibrillation. Circulation. 109:1640-1646. 
Wang, S., Zhang, P., Chen, F., \& Li, F. (2003). Correlation between ACE-I gene polymorphism and atrial fibrillation. Zhongguo Shiyong Neike Zazhi, 23, 537-538.

Wang, Y., Li, Y., Fan, J., Xu, Y. P., Xiao, P. L., Long, Y., Lin, Z. Y., Li, Z. F., \& Yin, Y. H. (2011). Correlation between polymorphism of ACE gene I/D and ACE2 gene A9570G and atrial fibrillation. Medical Journal of Chinese People's Liberation Army, 36(9), 904-908.

Wei ,L, Wei, W, Lu, G, \& Zhu, Z (2008). Study of association of polymorphism in angiotensin-converting enzyme insertion/deletion gene and $\beta 2$ adrenergic receptor 16 locus genes with atrial fibrillation. Medical Journal of National Defending Forces in Southwest China, 30(3), 495-498.

Yamashita, T., Hayami, N., Ajiki, K., Oikawa, N., Sezaki, K., Inoue, M., Omata, M., \& Murakawa, Y. (1997). Is ACE gene polymorphism associated with lone atrial fibrillation? Japanese Heart Journal, 38(5), 637-641. http://dx.doi.org/10.1536/ihj.38.637. PMid:9462412.

Yang, C., Liang, X., Huang, L., Xu, X., \& Zhai, L. (2009). Associations between Angiotensin Converting Enzyme (ACE), angiotensinogen
(AGT) and nonfamilial atrial fibrillation. Guangdong Yixue, 30, 86-87.

Zhang, F., Min, X., Zeng, Q., \& Li, G. (2011) Association of angiotensinconvertion enzyme (ACE) gene Alu I/D with atrial fibrillation. Journal of Clinical Cardiology, 15(2), 531-535.

Zhang, X.-L., Wu, L.-Q., Liu, X., Yang, Y.-Q., Tan, H.-W., Wang, X.-H., Zhou, L., Jiang, W.-F., \& Li, Z. (2012). Association of angiotensinconverting enzyme gene I/D and CYP11B2 gene $-344 \mathrm{~T} / \mathrm{C}$ polymorphisms with lone atrial fibrillation and its recurrence after catheter ablation. Experimental and Therapeutic Medicine, 4(4), 741-747. http://dx.doi.org/10.3892/etm.2012.650. PMid:23170137.

Zintzaras, E., Raman, G., Kitsios, G., \& Lau, J. (2008). Angiotensinconverting enzyme insertion/deletion gene polymorphic variant as a marker of coronary artery disease: A meta-analysis. Archives of Internal Medicine, 168(10), 1077-1089. http://dx.doi.org/10.1001/ archinte.168.10.1077. PMid:18504336. 